\title{
Immunological and Electrophoretic Characteristics of Anti-SGP Reacting Protein Among Component $-3,-5$ and -8 Fractions of Proteose-Peptone of Bovine Milk: Evidence for the Multiple Forms
}

\author{
Choemon Kanno and Yoshiyuki OHTake \\ Department of Animal Science, Utsunomiya \\ University, Utsunomiya-shi 321
}

(Received September 24, 1980)

\begin{abstract}
The anti-SGP reacting protein, the designation for the whey protein which react with the antiserum to the soluble glycoprotein (SGP) isolated from milk fat globule membrane, was studied immunologically and electrophoretically, using the fractions obtained by gel filtration on Bio Gel A- $0.5 \mathrm{~m}$ or chromatography on DEAE-cellulose of the component $-3,-5$ and -8 fractions of the proteose-peptone of bovine milk. The results of analyses on quantitative simple radial immunodiffusion, double immunodiffusion, immunoelectrophoresis, and disc electrophoresis of the obtained fractions suggested that a slow migrating band and band 3 were deeply in relation with the anti-SGP reacting protein. The precipitation lines of the fractions indicated positive reaction to the anti-SGP fused completely with each other and even among the component $-3,-5$ and -8 on double immunodiffusion, suggesting the presence of a set of antigenic determinant group. Inmunoelectrophoretic patterns of 9 fractions obtained by DEAE-cellulose chromatography of the component -3 showed that the migrating rate of the precipitation lines increased in the order of the fraction eluted through DEAE-cellulose. The results suggested that there were the multiple forms of the anti-SGP reacting protein. The anti-SGP reacting protein present in the component-5 and -8 did not correspond to all of them of the component-3 but did to some of them. It was tried to elucidate structural relationship between the anti-SGP reacting protein and SGP by sodium dodecyl sulfate-polyacrylamide gel electrophoresis. Two polypeptides (band $\mathrm{A}$ and $\mathrm{B}$ ), appeared to be common to both proteins. The multiple forms of the anti-SGP reacting protein seemed to be formed by intermolecular association of two major polypeptides with other minor polypeptides. There was no evidence that the anti-SGP reacting protein was derived from bovine serum.
\end{abstract}

Jpn. J. Zootech. Sci., 52 (4):282-296, 1981

Milk fat globule membrane (MFGM) is derived from the apical plasma membrane of the lactating mammary gland and has an important property for dispersion of fat globule in milk ${ }^{\mathbf{1} 2)}$. Of many glycoproteins constituting MFGM, the soluble glycoprotein (SGP) is a protein localized in the outer surface of fat globules ${ }^{3-8)}$. It was found by KanNo and YAMAUCHI ${ }^{9.10}$ ) that the protein which react with the antiserum to SGP of MFGM, called as the anti-SGP reacting protein, was present in the heat-stable protein fraction of bovine milk whey: the component-3, -5 and -8 fractions of proteose-peptone. Chemical and physicoshemical characteristics of the component- 3 fraction, in which the anti-SGP reacting protein was mostly concentrated, were markedly different from those of $\mathrm{SGP}^{10}$ ). In addition, immunodiffusion tests showed that the 
anti-SGP reacting protein among three component fractions of proteose-peptone had identical antigenicity, while the mobility of the precipitation lines of the anti-SGP reacting protein on immunoelectrophoresis were slightly different among each component fraction. The previous results also suggested that the anti-SGP reacting protein contained in the three component fractions had different molecular structure. It is, therefore, necessary to make clear differences of the anti-SGP reacting protein among the component- $3,-5$ and -8 fractions of proteose-peptone. In the present study, immunological and electrophoretical properties of the anti-SGP reacting protein of three component fractions were examined, using the fractions obtained by gel filtration on Bio Gel A-0.5 m and ion exchange chromatography on DEAE-cellulose of three component fractions. Structural relationship between the anti-SGP reacting protein and SGP was tried to elucidate.

\section{Materials and Methods}

\section{Materials}

Bio Gel A-0.5 m (100-200 mesh) and DEAE-cellulose DE 52 were purchased from Bio-Rad Laboratories (Richmond, U.S. A.) and Whatman Ltd. (Maidstone, England), respectively. Agar (special agar nobel) and complete and imcomplete Freund adjuvants were obtained from DEFCO Laboratories (Detroit, U.S. A.). Anti-bovine serum (rabbit) and bovine serum albumin were obtained from Miles Laboratories (Elkhart, U.S.A.).

Preparation of component $-3,-5$ and -8 fractions

The proteose-peptone fraction was prepared and fractionated with ammonium sulfate to the component- $3,-5$ and -8 fractions by the method of NG et al. ${ }^{11}$ ) and KoLAR and BRUNNER ${ }^{12)}$, as described previously ${ }^{10}$ ).

Preparation of soluble glycoprotein

The soluble glycoprotein of MFGM was prepared from bovine milk by the procedure described previously's.

Immunological experiments

Preparation of the antiserum to SGP of MFGM, Ouchterlony double immunodiffusion $^{13)}$, immunoelectrophoresis ${ }^{14}$, and quantitative simple radial immunodiffusion ${ }^{15}$ were performed as described in the previous papers ${ }^{9.10}$.

\section{Gel filtration}

Gel filtration was performed on Bio Gel A- $0.5 \mathrm{~m}(2 \times 95 \mathrm{~cm})$ equilibrated with $0.1 \mathrm{M}$ Tris- $\mathrm{HCl}$ buffer, $\mathrm{pH} 8.6$, containing $0.02 \%$ sodium azide. Protein was eluted with the same buffer and monitored at $280 \mathrm{~nm}$. A flow rate was $11 \mathrm{~m} l$ per hour. The eluted fractions were dialyzed against distilled water and freeze-dried.

Ion exchange chromatography

DEAE-cellulose DE 52 washed with acid and base was equilibrated with $0.01 \mathrm{M}$ Tris-phosphoric acid buffer, $\mathrm{pH} 8.6$, and poured into a column $(2 \times 20 \mathrm{~cm})$ with positive pressure. After equilibration with the starting buffer, protein dissolved in the starting buffer was applied to the column. The elution was performed with a linear gradient of $600 \mathrm{ml}$ of each of 0.01 and $0.5 \mathrm{M}$ Tris-phosphoric acid buffer, pH 8.6. 
At the end of the gradient elution, the materials still bound to the column was eluted with 0.5 or $1.0 \mathrm{M}$ Tris-phosphoric acid buffer, $\mathrm{pH} 8.6$. The flow rate was $50 \mathrm{ml}$ per hour and the concentration of protein was scanned at $280 \mathrm{~nm}$. The eluted fractions were dialyzed against distilled water and freeze-dried.

\section{Electrophoresis}

Disc electrophoresis was performed by the procedure of DAvis ${ }^{16)}$ as described previously ${ }^{10)}$. Acrylamide concentration was $9 \%$. Polyacrylamide gel electrophoresis in the presence of sodium dodecyl sulfate (SDS-PAGE) was carried out by the method of WEBER and OsBorn ${ }^{17}$. Acrylamide concentration was 10\%. Protein and carbohydrate were stained with coomassie brilliant blue R-250 and periodic acid-Schiff reagent respectively, as decribed previously ${ }^{10}$.

\section{Results and Discussion}

\section{Fractionation of component-3, -5 and -8}

Each component was fractionated into 5 to 6 fractions by gel filtiation on Bio Gel A-0.5 m (Fig. 1). Elution patterns of three component fractions were almost similar except that the fraction 2 observed in the component-3 and -8 was lacking in the component -5 and the fraction 4 of the component- 8 was relatively eluted more slowly than that of the component-3 and -5 . Distribution of total protein in each fraction recovered through the column was shown in Table 1 . Most of protein was recovered in the fraction 1 to 4 for the component-3, fraction 1 to 4 for the component-5, and fraction 2 to 4 for the component-8. Apparently a large peak of the fraction 1 eluted at the void volume for the component -5 was due to the turbidity of the solution.

Fig. 2 shows elution patterns obtained by DEAE-cellulose chromatography of three component fractions. Each component was fractionated into 8 to 12 fractions. The fraction corresponding to the fraction 6 of the component-3 was peculiar to the component-5 and -8. Distribution of total protein recovered in each fraction was also shown in Table 2. Most of protein was recovered in the fraction 9 and 10, fraction 6 to 8 , and fraction 10 and 12 for the component-3, -5 and -8 , respectively.

Concentration of anti-SGP reacting protein

The concentration of the anti-SGP reacting protein in each fraction obtained by Bio Gel A-0.5 m and DEAE-cellulose was measured by the quantitative simple radial immunodiffusion analysis (Table 1 and 2). Of the fractions obtained by gel filtration, the highest concentration of the anti-SGP reacting protein was found in the fraction 2 for the component-3 and -8 and fraction 1 for the component-5. Most of the antiSGP reacting protein distributed in the fraction 1 to 3 for the component-3 and -5 and the fraction 2 to 4 for the component-8. On the other hand, of the fractions obtained by DEAE-cellulose chromatography the highest concentration of the anti-SGP reacting protein was found in the fraction 3 of the component-3, suggesting that the protein apparently is anti-SGP reacting protein. Distribution of the recovered antiSGP reacting protein was low in fractions which contained a relatively high amounts of the anti-SGP reacting protein, while it was high in the fractions which eluted by 
Multiple Forms of Anti-SGP Reacting Protein
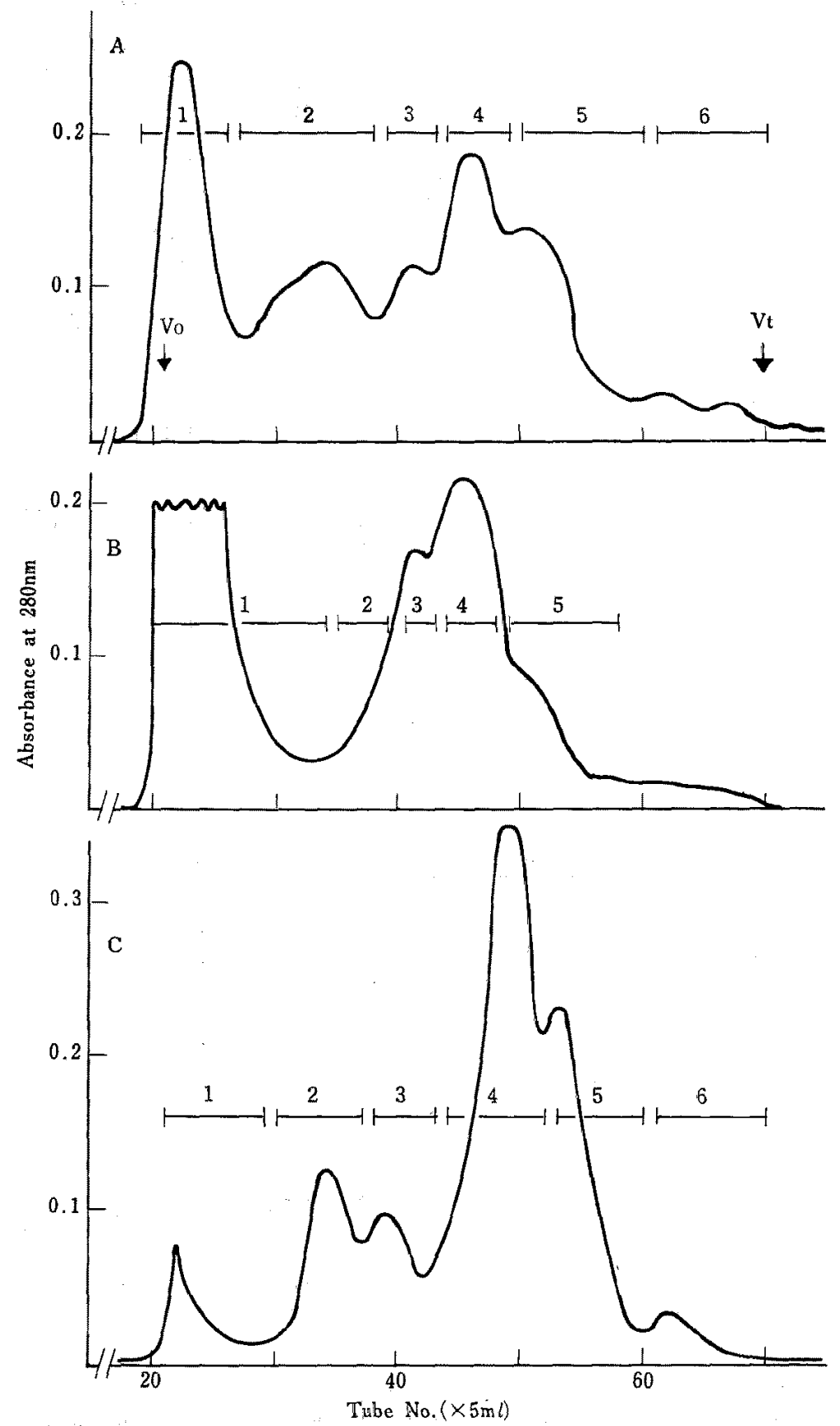

Fig. 1. Gel filtration patterns on Bio Gel $\mathrm{A}-0.5 \mathrm{~m}$ of the component-3 (A), -5 (B) and $-8(\mathrm{C})$. Amounts of charged protein were 81,84 and $82 \mathrm{mg}$ of the component -3 , -5 and -8 , respectively. 

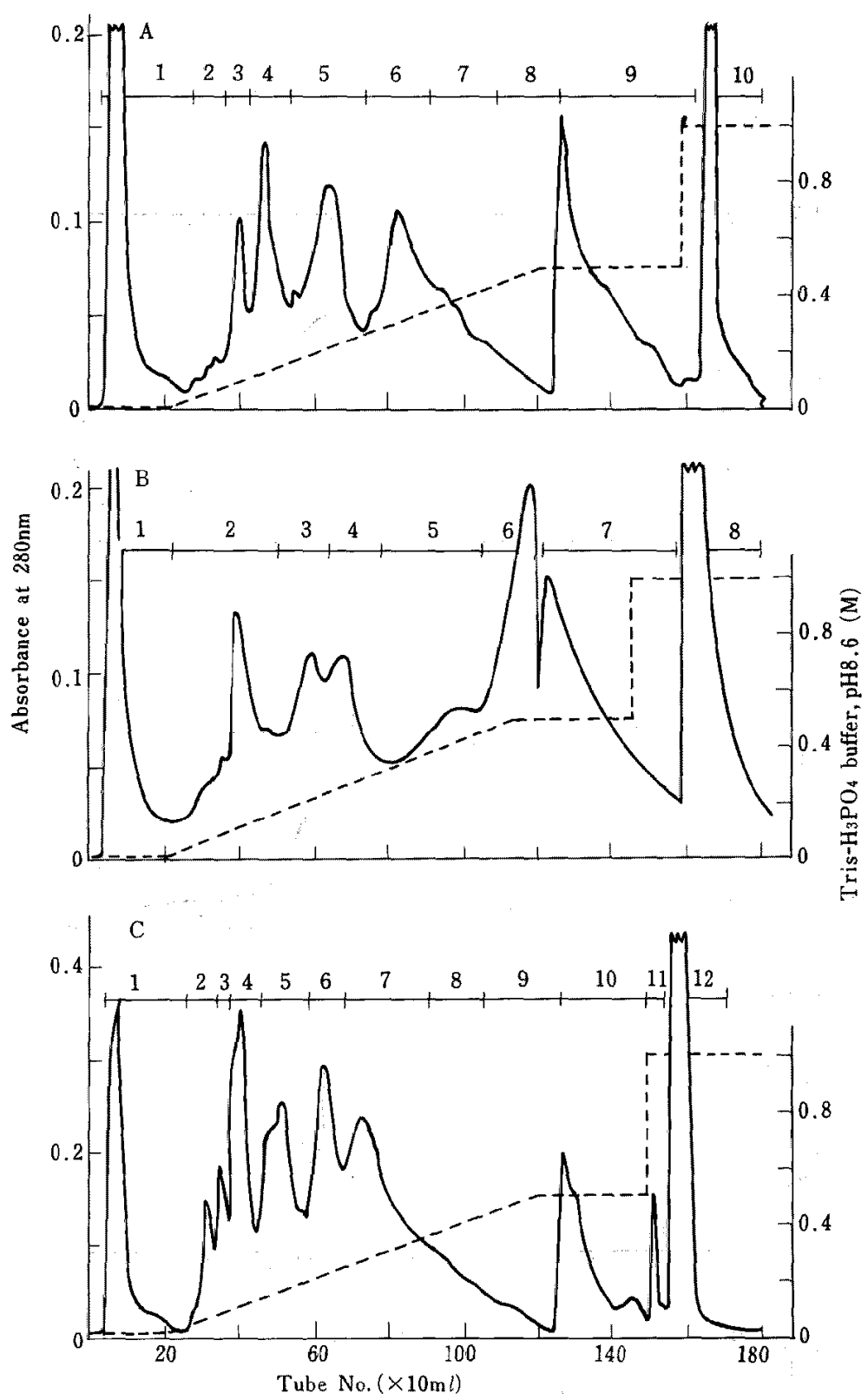

Fig. 2. Elution patterns on DEAE-cellulose chromatography of the component-3 (A), -5 (B) and -8 (C). Amounts of the charged protein were 600,712 and 715 $\mathrm{mg}$ of the componet $-3,-5$ and -8 , respectively.

a high concentrated elution buffer, being due to the amounts of the recovered total protein. Especially in a case of the component-3, a relatively high concentration of the anti-SGP reacting protein was eluted throughout every fraction. Differences of concentration and distribution of the anti-SGP reacting protein among component-3, -5 and -8 suggest that properties of the anti-SGP reacting protein present in the respec- 
Multiple Forms of Anti-SGP Reacting Protein

Table 1. Concentration and distribution of total protein and the anti-SGP reacting protein of the fractions obtained by gel filtration on Bio Gel A-0.5 m of the component-3, -5 and -8 .

\begin{tabular}{|c|c|c|c|}
\hline & \multirow{2}{*}{$\begin{array}{l}\text { Distribution } \\
\text { of total } \\
\text { protein } \\
(\%)\end{array}$} & \multicolumn{2}{|c|}{ Anti-SGP reacting proteir } \\
\hline & & $\begin{array}{c}\text { Concentration } \\
(\%)\end{array}$ & $\begin{array}{l}\text { Distribution } \\
(\%)\end{array}$ \\
\hline Component-3 & 100 & 40.4 & 100 \\
\hline Fraction 1 & 15 & 58.4 & 16.1 \\
\hline Fraction 2 & 29 & 95.1 & 51.5 \\
\hline Fraction 3 & 19 & 72.5 & 24.9 \\
\hline Fraction 4 & 29 & 10.8 & 5.8 \\
\hline Fraction 5 & 7 & 10. 2 & 1.5 \\
\hline Fraction 6 & 1 & 10.2 & 0.3 \\
\hline Component-5 & 100 & 14.7 & 100 \\
\hline Fraction 1 & 21 & 41.0 & 48.2 \\
\hline Fraction 2 & 34 & 14.1 & 26.4 \\
\hline Fraction 3 & 32 & 10.2 & 18.3 \\
\hline Fraction 4 & 11 & 11.3 & 7.1 \\
\hline Fraction 5 & 1 & nd & nd \\
\hline Component-8 & 100 & 14.5 & 100 \\
\hline Fraction 1 & 3 & 14.6 & 3.4 \\
\hline Fraction 2 & 15 & 25.1 & 30.1 \\
\hline Fraction 3 & 16 & 16.9 & 22.1 \\
\hline Fraction 4 & 59 & 8.2 & 39.5 \\
\hline Fraction 5 & 7 & 9.4 & 5.0 \\
\hline Fraction 6 & 0.4 & nd & nd \\
\hline
\end{tabular}

nd, not determined.

tive component may be different.

\section{Electrophoretic properties}

The fractions obtained by gel filtration were analyzed on disc gel electrophoresis (Fig. 3). Each component fraction contained many bands. Band 3,5 and 8 were specific and major for the component $-3,-5$ and -8 , respectively, in agreement with the previous results ${ }^{10)}$. Band 3 also was densely observed in the fractions which were rich in the amounts of the anti-SGP reacting protein: the fraction 2,1 and 2 for the component $-3,-5$ and -8 , respectively. It was suggested that band 3 related to the antiSGP reacting protein.

Disc electrophoretic analysis of the fraction obtained by DEAE-cellulose chromatography revealed more detailed patterns for the anti-SGP reacting protein, especially for the component-3 (Fig. 4). A broad band having relatively smaller mobility than that of band 3 was eluted in the fraction 2 to 4 for the component-3. Band 3 was eluted in the fraction 5 to 10 . In the component-5, band 3 was detected in the fraction 4 to 8 but not so dense as that of the component-3. A slower migrating band was not observed. In the component- 8 , a slower migrating band in the fraction 3 was 


\section{KanNo and OHTAKe}

Table 2. Concentration and distribution of total protein and the anti-SGP reacting protein of the fractions obtained by DEAEcellulose chromatography of the component $-3,-5$ and -8 :

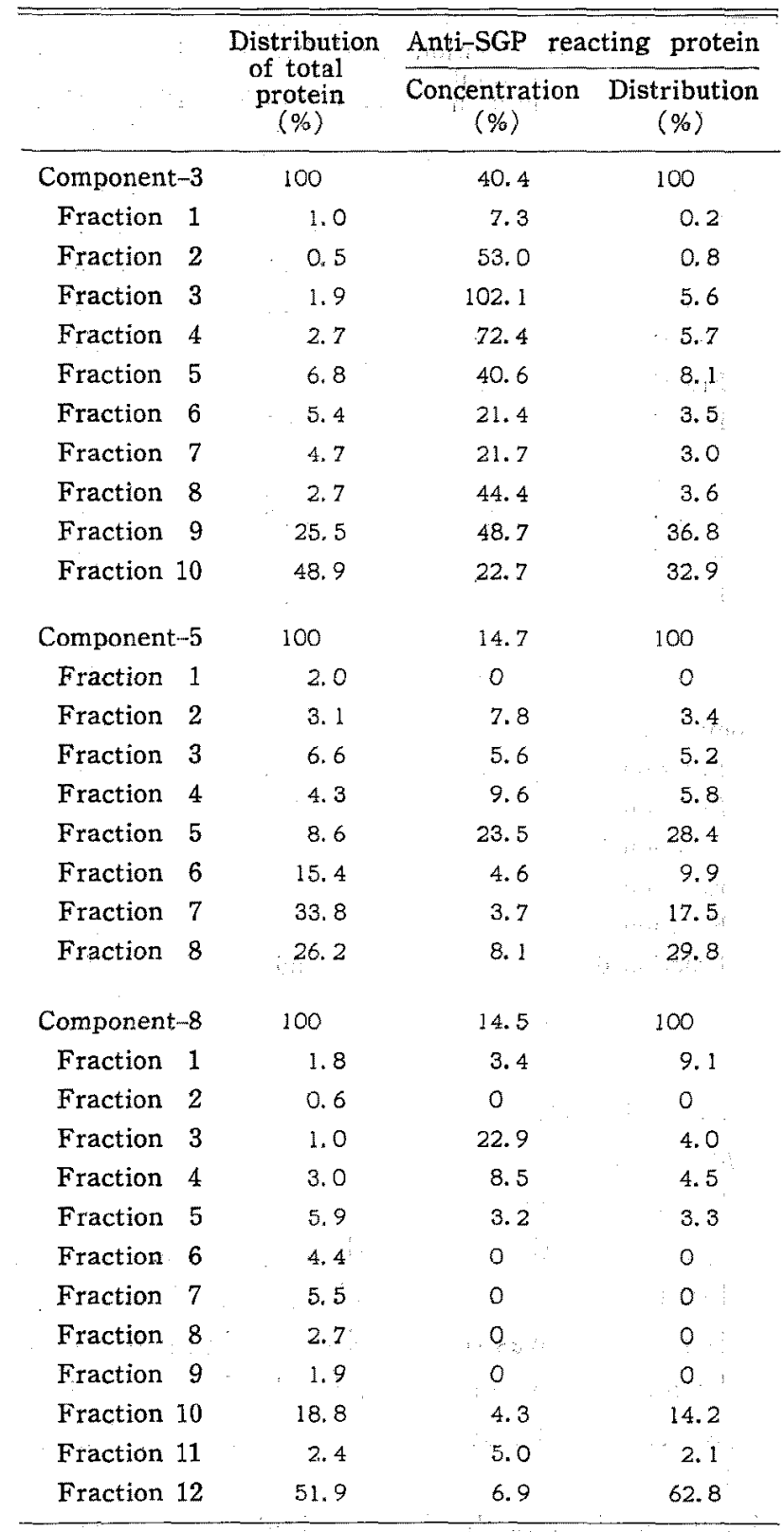

similar to that of the fraction 4 of the component-3. Band 3 was not observed profoundly in the fractions of the component-8. It was found newly in the present study that a slower migrating band observed in the fraction 2 to 4 of the component-3 and the fraction 3 of the component- 8 seemed to have a connection with the anti-SGP reacting protein, speculating from the amounts of the anti-SGP reacting protein 

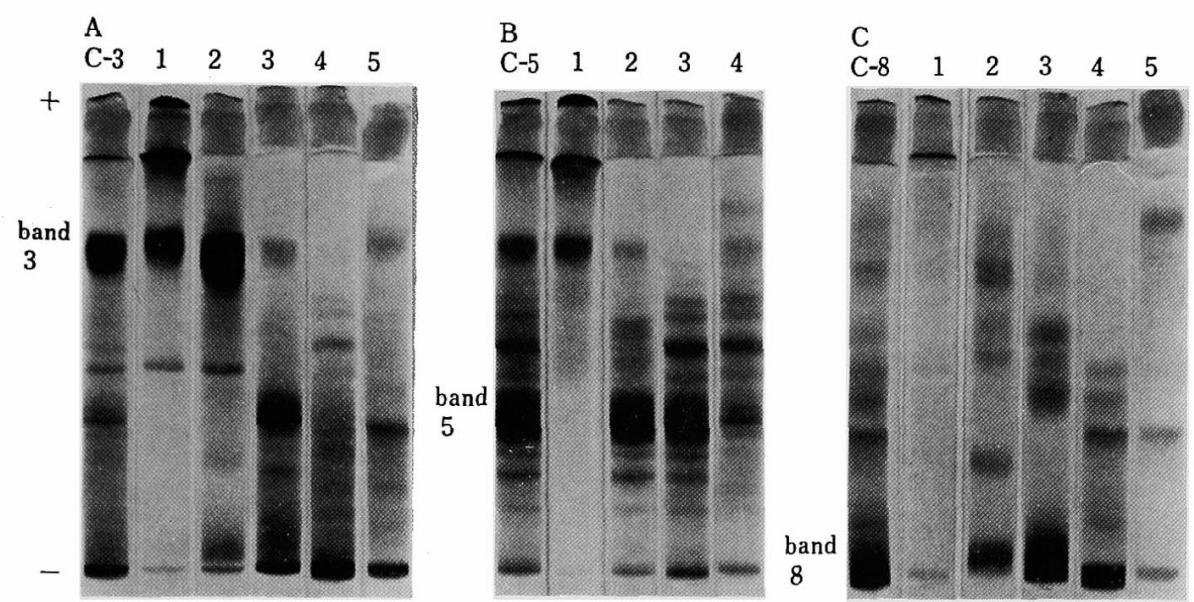

Fig. 3. Disc electrophoretic patterns of the fractions obtained by gel filtration on Bio Gel A- $0.5 \mathrm{~m}$ of the component-3 (A), -5 (B) and -8 (C). C-3, component -3 ; C-5, component -5 ; C-8, component-8. Numerals in the figure indicate the fraction obtained by gel filtration shown in Fig. 1. Proteins were stained by coomassie blue.

(Table 2).

The results of electrophoretic analysis suggested that two proteins of a slow migrating band and band 3 had relations with the anti-SGP reacting protein. In addition, the anti-SGP reacting protein present in the component-3 appeared to be contained partially in the component -5 and -8 .

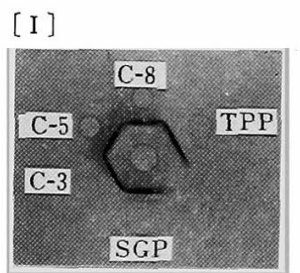

[II ] A

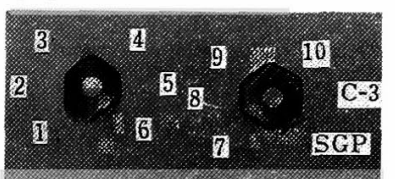

A

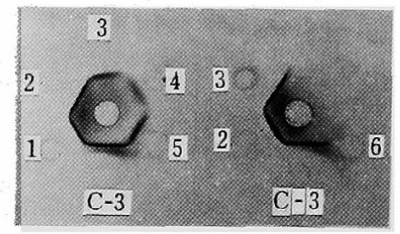

$\mathrm{B}$

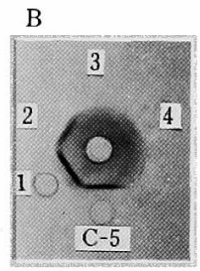

C
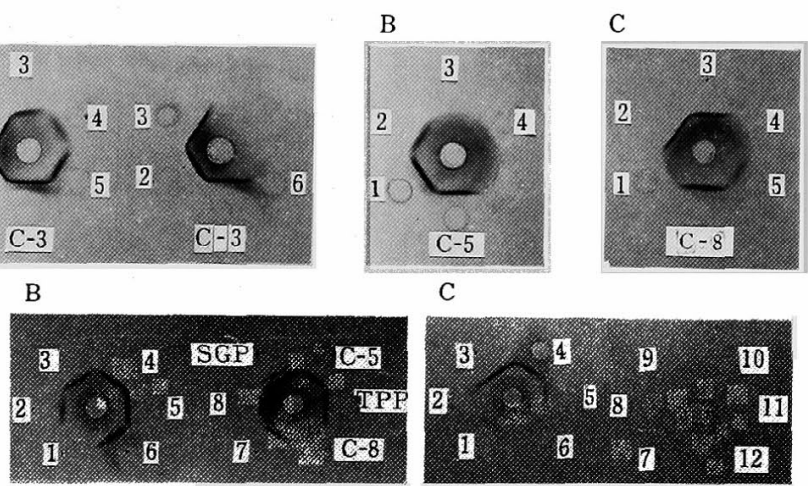

[III]
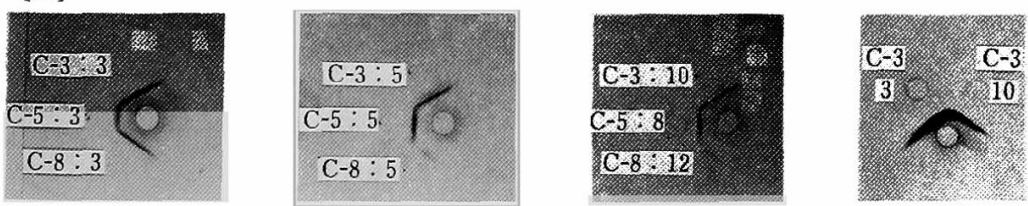

Fig. 5. Double immunodiffusion assays of the fractions obtained by gel filtration on Bio Gel A $-0.5 \mathrm{~m}$ (I) and DEAE-cellulose chromatography (II, III) of the component-3 (A), -5 (B) and -8 (C). TPP, total proteose-peptone; $\mathrm{C}-3$, component $-3 ; \mathrm{C}-5$, component $-5 ; \mathrm{C}-8$, component -8 ; SGP, soluble glycoprotein. Numerals in the figure indicate the fraction shown in Fig. 1 for Bio Gel A-0.5 m and Fig. 2 for DEAE-cellulose. III shows the cross reactivity among the components. Center well contains the antiserum to SGP. 


\section{Kanno and Ohtake}

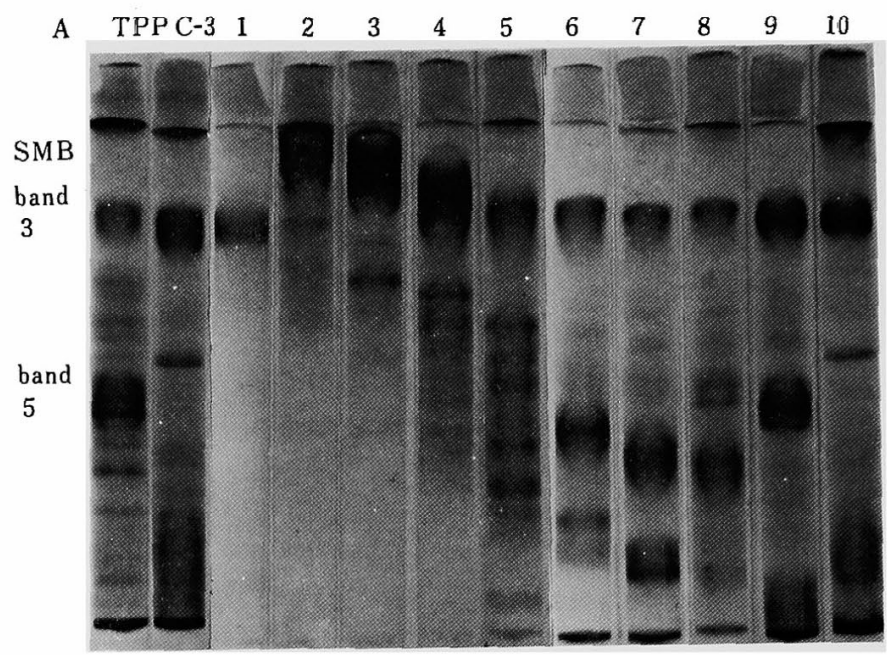

Fig. 4. Disc electrophoretic patterns of the fractions obtained by DEAE-cellulose chromatography of the component-3 (A), -5 (B) and -8 (C). TPP, total proteose-peptone; C-3, component3 ; C-5, component -5 ; C-8, component -8 ; SGP, soluble glycoprotein; SMB, slow migrating band. Numerals in the figure indicate the fraction obtained by ion exchange technique shown in Fig. 2. Proteins were stained by coomassie blue.
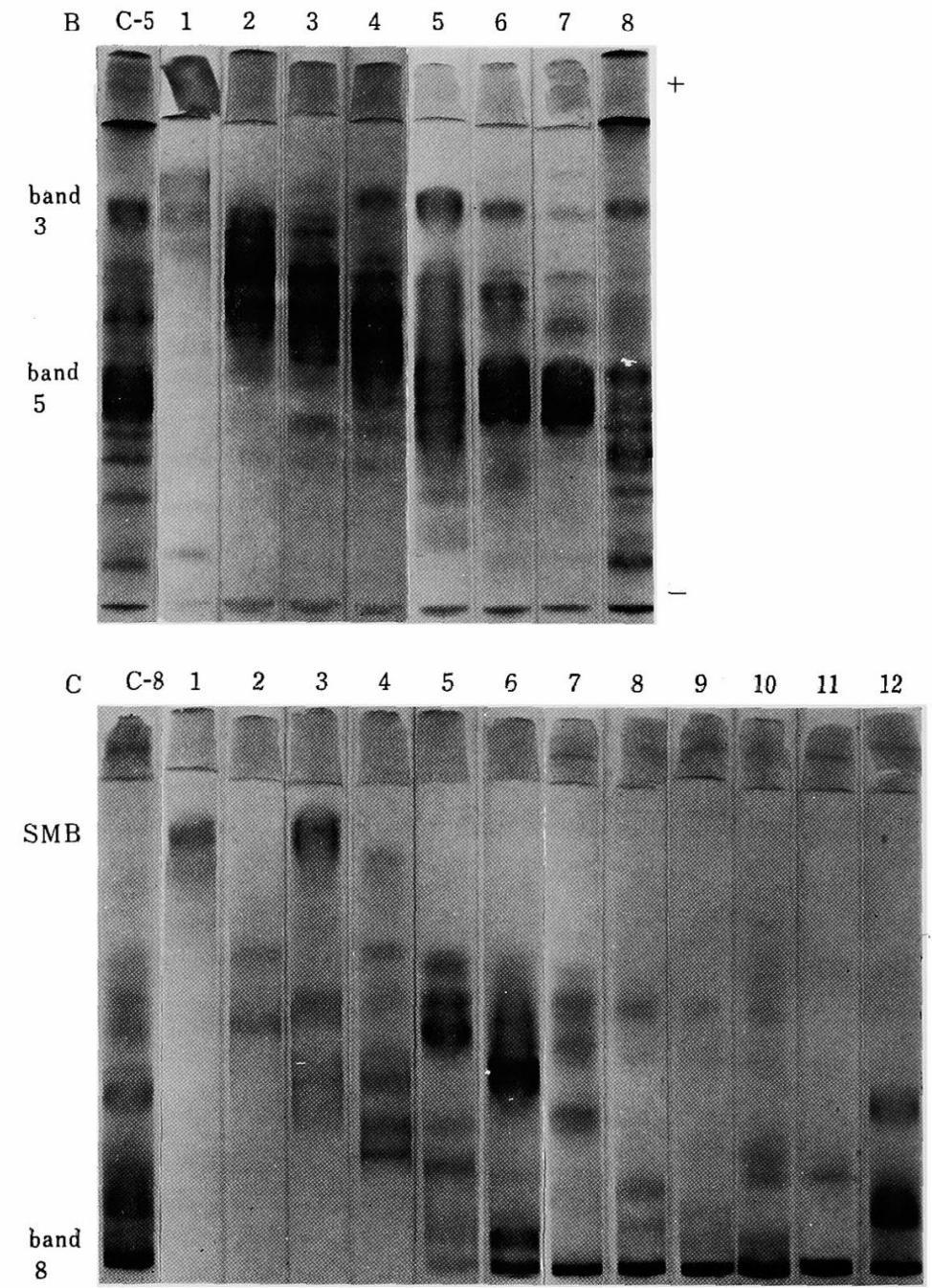
Multiple Forms of Anti-SGP Reacting Protein
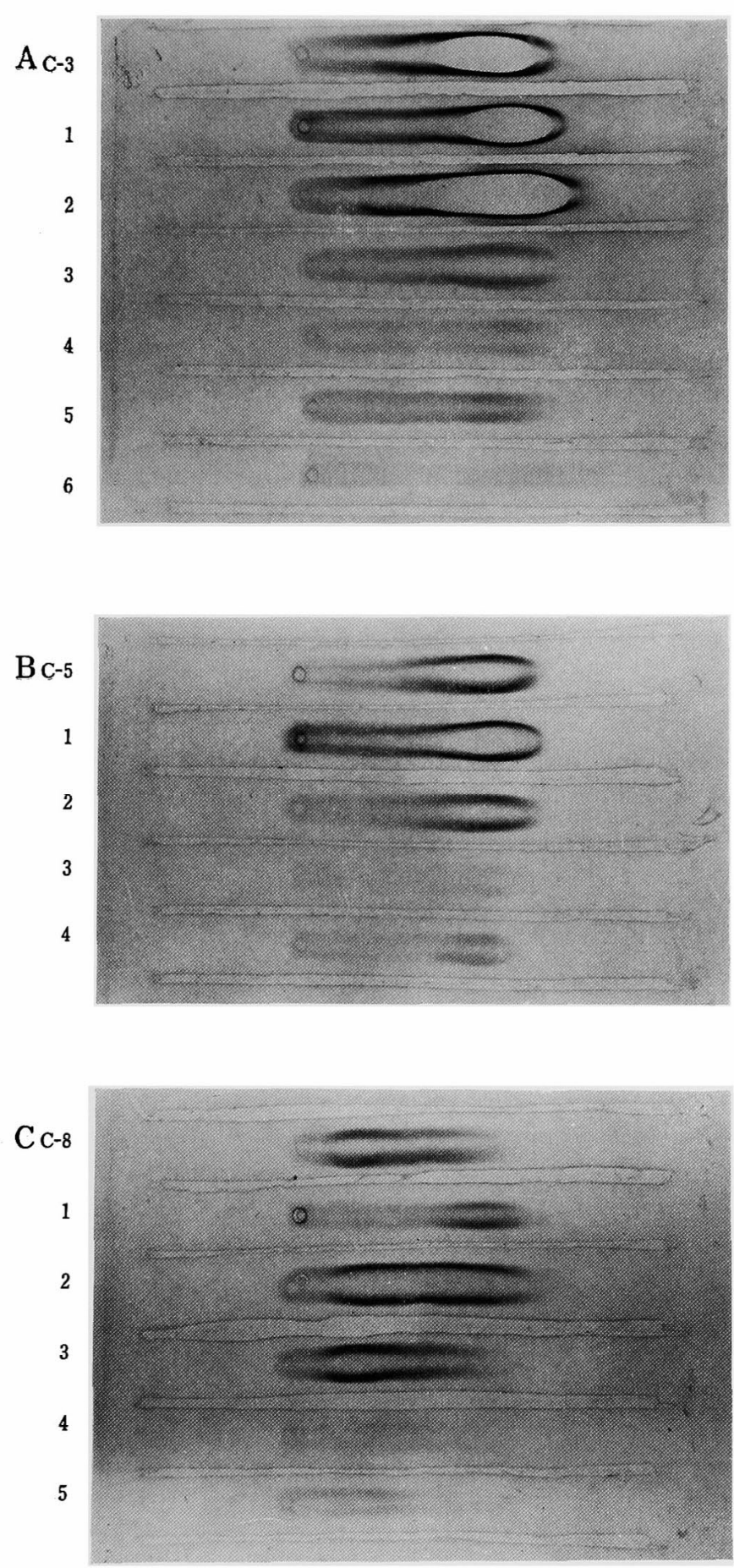

Fig. 6. Immunoelectrophoretic patterns of the fractions obtained by gel filtration on Bio GeJ A- $-0.5 \mathrm{~m}$ of the component -3 (A), -5 (B) and -8 (C). Numerals indicate the fraction shown in Fig. 1. Troughs contain the antiserum to SGP. C-3, component-3; C-5, component $-3 ; \mathrm{C}-8$, component-8. 


\section{Immunological properties}

On double immunodiffusion assays, the precipitation lines of total proteose-peptone, the component- $3,-5$ and -8 fused with the major line of SGP (Fig. 5-I), in ageement with the previous results ${ }^{9,10)}$. Of the fractions obtained by gel filtration, the fraction 1 to 5 of the component-3, fraction 1 and 2 of the component- 5 , and fraction 2 and 3 of the component- 8 were profoundly reacted with the antiserum to SGP and the pecipitation lines fused one another (Fig. 5-I). In addition, of the fractions obtained by DEAE-cellulose chromatography, the fraction 2 to 10 of the component-3, fraction 2 to 8 of the component-5, and fraction 1 and 3 to 5 of the component- 8 showed positive reaction to the anti-SGP (Fig. 5-II). They also depicted the fused precipitation lines.

The fractions, which have almost similar mobility on immunoelectrophoresis, among three component fractions fused with each other to the anti-SGP (Fig. 5-III).

The results suggest that antigens shown the positive reaction have a set of identical determinant group to the anti-SGP, in agreement with the previous results ${ }^{10}$.

Immunoelectrophoretic patterns showed the presence of multiple forms of the antiSGP reacting protein in the fractions obtained herein (Figs. 6 and 7). In general, the results with respect to reactivity to anti-SGP were in agreement with those of double immunodiffusion and simple radial immunodiffusion assays. The fractions obtained by gel filtration depicted a long precipitation line from the origin. Furthermore, immunoelectrophoretic patterns of the separated fractions of the component-3 through DEAE-cellulose showed that the migrating rate of the precipitation line increased in the order of the eluted fraction. Such behavior was also observed in both the component-5 and -8 . A long precipitationline observed in the fraction obtained by gel filtration was likely to contain the anti-SGP reacting protein corresponding to the several fractions separated by ion exchange technique. Especially, band 3 which has similar mobility on disc electrophoretic pattern showed the increased mobility in the eluted order on agar gel, as seen in Figs. 4-A and 7-A.
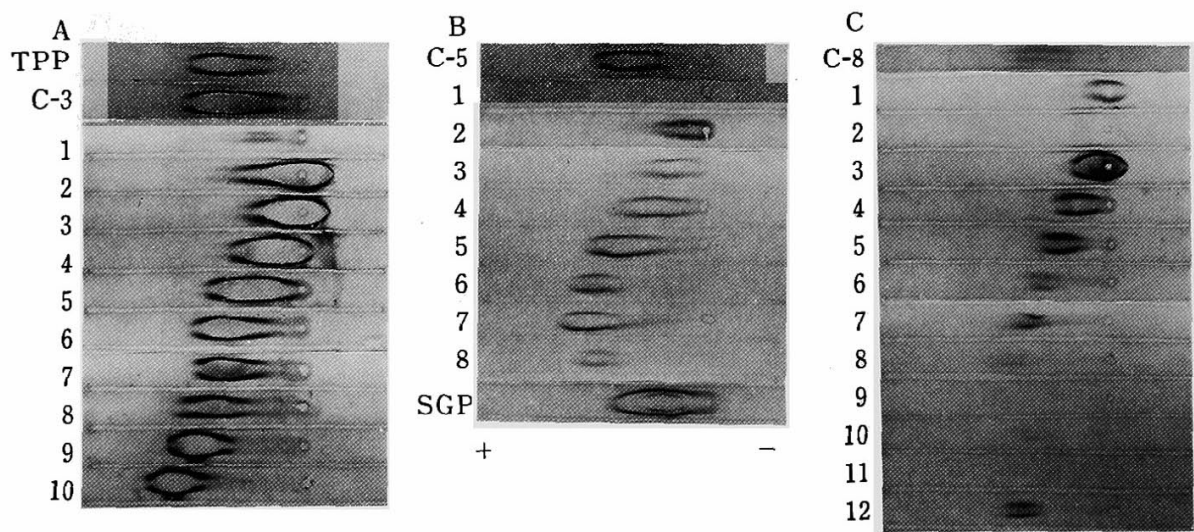

Fig. 7. Immunoelectrophoretic patterns of the fractions obtained by DEAE-cellulose chromatography of the component-3 (A), -5 (B) and -8 (C). Numerals indicate the fraction shown in Fig. 2. TPP, total proteose-peptone; C-3, component-3; C-5, component -5 ; $\mathrm{C}-8$, component -8 ; SGP, soluble glycoprotein. Troughs contain the antiserum to SGP. 


\section{Multiple Forms of Anti-SGP Reacting Protein}

There were the multiple forms of proteins which react with the anti-SGP, in spite of identical antigenicity. The anti-SGP reacting protein present in the component5 and -8 did not correspond to all of them of the component-3 but did to some of them. It is, therefore, considered that the anti-SGP reacting protein contained among three component fractions probably may differ in their intermolecular structure.

\section{Reactivity with anti-bovine serum}

The reactivity of the anti-SGP reacting protein with the anti-bovine serum was tested. As shown in Fig. 8, the cross reactivity to the anti-bovine serum was observed only in the fraction 5 to 10 obtained by DEAE-cellulose chromatography of the component-8. The fraction 1 to 4 of the component- 8 and the fractions of the component-3 and -5 did not react with the anti-bovine serum (figure not shown). The mobility of the precipitation line of the protein which react with the anti-bovine serum was somewhat different among the eluted fractions (Fig. 8-II). More detailed patterns were shown in Fig. 8-III and -IV, in which the lines of such protein were different
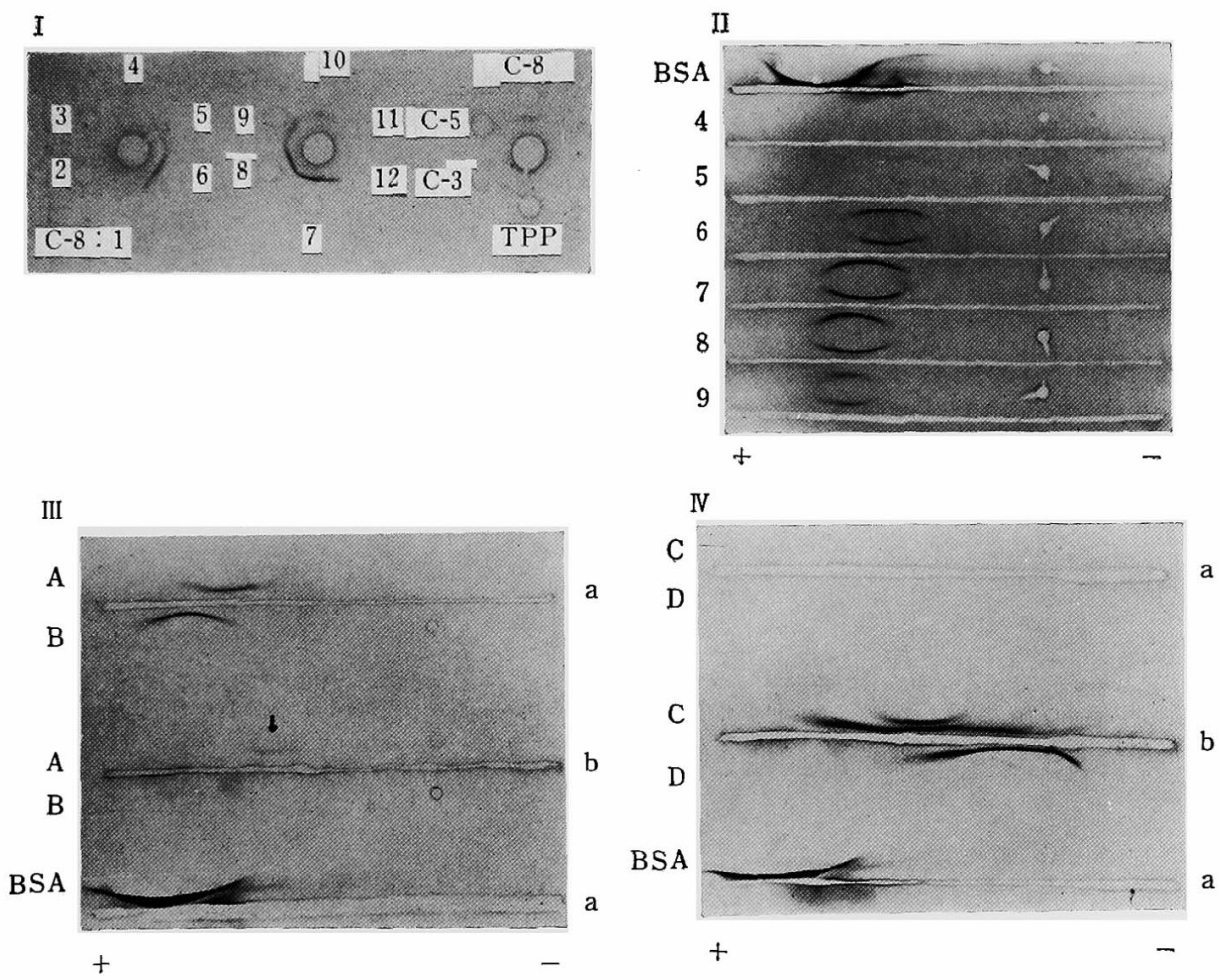

Fig. 8. Immunological assays of the fractions obtained by DEAE-cellulose chromatography to the anti-bovine serum. Numerals on double immunodiffusion (I) and immounoelectrophoretic patterns (II) to the anti-bovine serum indicate the fraction of the component- 8 shown in Fig. 2. TPP, total proteose-peptone; C-3, component $-3 ; \mathrm{C}-5$, component $-5 ; \mathrm{C}-8$, component -8 ; BSA, bovine serum albumin. In III and IV, A, fraction 6 of component-8; B, fraction 8 of component-8; C, soluble glycoprotein; D, fraction 4 of component -3 . Trough a. contains the anti-bovine serum and b. the antiserum to SGP. B to the anti-SGP (III:b) and C and D to the anti-bovine serum (IV: a) did not show the detectable precipitation lines. Arrow in III shows the presence of the precipitation line detected faintly. 
from those of the anti-SGP reacting protein and bovine serum albumin. In addition SGP and the fraction 4 of the component-3 did not react with the anti-bovine serum. The anti-SGP reacting protein, therefore, is not originated from bovine serum. The protein which react with anti-bovine serum was not identified in the present study.

Comparison of anti-SGP reacting protein with $S G P$

SGP is known to be consisted of eight polypeptides and also to be heterogeneous immunologically ${ }^{4,5}$. In order to elucidate the structural relationship between the antiSGP reacting protein and SGP, the fraction rich in the anti-SGP reacting protein obtained by chromatography on DEAE-cellulose of the component- $3,-5$ and -8 were analyzed on SDS-PAGE (Fig. 9). By both protein and carbohydrate staining, the fractions analyzed herein consisted of many polypeptides. The major polypeptide, band $\mathrm{A}$, was found commonly throughout the analysed fractions. Band A also corresponded to the major band of SGP; CB-I+II (PAS-IV+V) ${ }^{4}$. Patterns of the fraction 3 ( 1 and 5 of Fig. 9) of the component- 3 and -8 , which are the most abundant in the antiSGP reacting protein, were very similar to that of SGP by protein staining. By carbohydrate staining, however, their fractions did not contain glycopeptides with relatively high molecular weights as detected in SGP. Band A probably corresponds to the slow
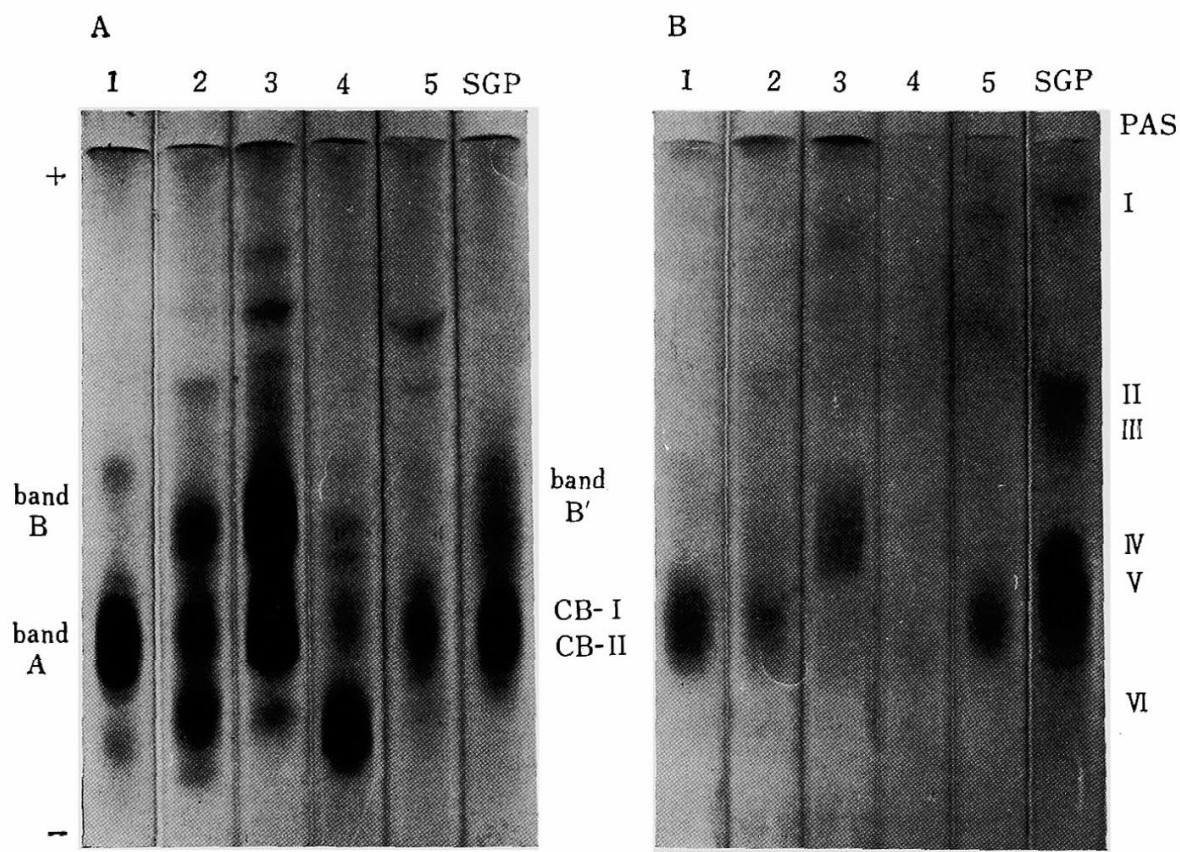

Fig. 9. Electrophoretic patterns on polyacrylamide gels in the presence of sodium dodecyl sulfate of the major fractions obtained by DEAE-cellulose chromatography of the component- 3 , -5 and -8 . A. protein staining; $B$, carbohydrate staining. 1,2 and 3 were the fraction 3,5 and 9 of the component -3 , respectively; 4 , fraction 3 of the component $-5 ; 5$, fraction 3 of the component-8. A symbol for polypeptides of SGP was in accordance with the previous paper ${ }^{4)}$. Apparent molecular weights of polypeptides of SGP were 88,000 for PSA-I, 40, 000 for PAS-II, 33,000 for PAS-III, 20,000 for PAS-IV (CB-I), 17,000 for PAS-V (CB-II), and 12,000 for PAS-VI ${ }^{4}$. 
migrating band detected on disc electrophoresis (Fig. 4). On the other hand, band B was detected as the major polypeptide in the fraction 9 of the component- 3 by both staining (Fig. 9-3). This band corresponds to band $\mathrm{B}^{\prime}$ of SGP, which is detectable faintly by protein staining but not by carbohydrate staining. Band B may be dissociated from band 3 with SDS (Fig. 3 and 4). Two polypeptides (A and B) were likely to be common to both the anti-SGP reacting protein and SGP and to be the cause of a set of antigenic determinant group to the anti-SGP. In addition, it was considered that the multiple forms of the anti-SGP reacting protein was formed by intermolecular association of two major polypeptides with other minor polypeptides. The anti-SGP reacting protein, therefore, seemed to have different mobility on immunoelectrophoresis and depict complete fusion rather than spur to the anti-SGP on double immunodiffusion.

Further resolution of structural and immunological relationship between the antiSGP reacting protein and SGP must await up to purification of the specimen which is in progress.

\section{References}

1) Patton, S. and T. W. Keenan, Biochim. Biophys. Acta, 415: 273-309. 1975.

2) KaNo, C., Jpn. J. Zootech. Sci., 51: 75-88, 1980.

3) Kanno, C., M. Shimizu and K. Yamauchi, Agric. Biol. Chem., 39: 1835-1842. 1975.

4) Shimizv, M., C. KanNo and K. Y.Mmauchi, Agric. Biol. Chem., 40: 1711-1716. 1976.

5) Kanno, C., M. Shimizu and K. Yamauchi, Agric. Biol. Chem., 41: 83-87. 1977.

6) Yamauchi, K., M. Shimizu and C. Kanno, J. Dairy Sci, 61: 688-696. 1978.

7) Shimizu, M., C. Kanno and K. Yamauchi, Agric. Biol. Chem., 42: 2309-2314, 1978.

8) Kanno, C., S. Nakamura and K. Yamauchi, Agric. Biol. Chem., 44: 1193-1194. 1980.

9) Kanno, C. and K. Yamauchr, Agric. Biol. Chem., 42: 1697-1705. 1978.

10) Kanno, C. and K. Yamauchi, Agric. Biol. Chem., 43: 2105-2113. 1979.

11) NG, W.C., J. R. Brunner and K. C. Rhee, J. Dairy Sci., 53: 987-996. 1970.

12) Kolar, K.C. and J. R. Brunner, J. Dairy Sci., 53: 997-1008. 1970.

13) Ouchterlony, O. and L. A. Nilsson, in Handbook of Experimental Immunology (WE1R, D. M. ed.) 2nd ed. Vol. 1, 19.1-19. 39. Blackwell Scientific Publications, Oxford. 1973.

14) Scheidegger, J. J., Int. Arch. Allergy, 7: 103-110. 1955.

15) Heremans, J.F., in Methods in Immunology and Immunochemistry (Williams, C.A. and M. W. Chase, eds.), Vol. 3. 213-224. Academic Press. New York. 1971.

16) Davis, B. J., Ann. N. Y. Acad. Sci., 121: 404-427. 1964.

17) Weber, K. and M. Osborn, J. Biol. Chem., 244: 4406 4412, 1969. 


\title{
牛乳のプロテオースペプトンの成分 $-3,-5$ およひ -8 \\ 画分に存在する Anti-SGP Reacting Protein $の$ \\ 免疫学的・電気泳動的特性
}

\author{
菅野長右工門・大武由之 \\ 宇都宮大学農学部, 宇都宮市 321
}

\begin{abstract}
牛乳脂肪球皮膜から得た可溶性蛋白質 (SGP) の抗体 と反応する蛋白質がホェーに存在することが見出され， これ学 anti-SGP reacting protein (A 蛋白質) と名付け た. A 蛋白質の大部分は耐熱性のプロテオースペプトン の成分 -3 K含安れているが, 成分 -5 と-8 kも存在卞 る。ここでは， 3 成分間のA蛋白質の性質の差罢および A 蛋白質と SGP の構造的・免疫学的関連を明らかにす るために，各成分を Bio Gel A-0.5 m によるゲル沪過お よび DEAE-cellulose クロマトグラフィーで分画した面 分を用いて研究した．得られた各成分の画分虎一元平板 兔疫拡散, 二重免疫拡散，免疫電気泳動，予よび Disc 電気泳動で分析した結果は互に一致していたことから， A 㔻白質には移動度の小さい゙ンド (SMB) とバンド 3 の 2 つの蛋白質が関連していることが示唆された.また 各画分の沈降線は各成分の画分間に执いてさ克融合して
\end{abstract}

いたから，A 蛋白質は同一の抗原決定群をすっているこ とが判明した. 成分一 3 を DEAE-cellulose クロマトグラ フィーで分画した画分の免疫電気泳動パターンにおける 沈降線の移動度は溶出された画分の順に堌大していた。 このことから，多様な形のA蛋白質が存在することが判 明した。ささらに，A 蛋白質とSGP の棈造的関連を SDSPAGE で調べた結果, 少なくとも 2 種の糖ぺプチド (band A およびB) が再者に共通していた。したがって， A 蛋白質が同一の抗原決定群意孔つにもかからず，多 様な形をとることは，A 蛋白質が主要な 2 種の糖ぺプチ ドとその他のポリぺプチドの分子間会合によって形成さ れていることに起因するものと考えられた。 また A蛋白

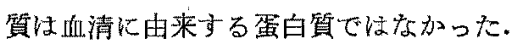

日畜会報，52(4)：282-296，1981 